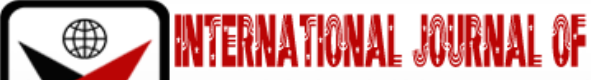

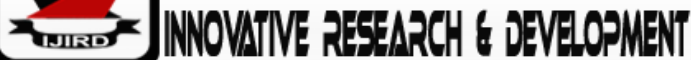

ISSN 2278-0211 (Online)

\section{Effectiveness of Teaching and Learning Materials in Large Class Size to Enhance Students' Academic Performance in Arumeru District, Tanzania}

\begin{tabular}{c}
\hline $\begin{array}{c}\text { Godfrey Msofe } \\
\text { Master's Candidate, Department of Education, Mwenge Catholic University, Tanzania } \\
\text { GadiKoda }\end{array}$ \\
Lecturer, Department of Education, Mwenge Catholic University, Tanzania \\
Paschal Wambiya \\
Lecturer, Department of Education, Mwenge Catholic University, Tanzania \\
\hline
\end{tabular}

\begin{abstract}
:
This study has the primary objective to find out the importance and usefulness of teaching and learning materials for overcrowded or large classes. The research area is in Arumeru District, Tanzania. Social Constructivism Theory has been used for this study. Mixed method approach has been deployed. Sample consists of four heads of schools, fortyeight faculties, and hundred and sixty students from four public secondary schools. Various data collection instruments have been used. Some of them are questionnaires, observation guide and in-depth interview guides. SPSS has been used for analysis. The study revealed that teachers in large class size considered teaching and learning materials as key to academic performance. The study also revealed that teaching learning materials has direct association with student's performance. Some recommendations related to government policies also have been provided during this study.
\end{abstract}

Keywords: Large class size, students' performance, teaching and learning materials, teacher strategies

\section{Introduction}

Education is a fundamental human right as well as a catalyst for economic growth and human development (Okumu et al., 2008). Good education students obtain depend on the several factors including school environment, availability of competent teachers, availability of teaching and learning materials and good classroom conduction. The classroom can be described as that place within the school where the teacher and students can be located regularly, where everyone supposedly knows one another and one in which everyone works together (Tebabal\&Kahssay, 2011). Class size refers to the actual number of students in any natural classroom. It is the number of students for whom a teacher is primarily assigned during a school year. Therefore, when classes are large might affect the effective teaching process. There are might be the problems of identification and that of being able to organise students to work together as a group.

Large classes are those where the students/teacher ratio (STR) exceeds the recommendation of the educational policy of a given country. STR is the number of students in a school with respect to the number of teaching staff (Koc\&Celik, 2015). The number of students per teacher is generally associated with class size and it is mainly believed that smaller classes provide a better teaching and learning environment. Class size has become a phenomenon often mentioned in the educational literature as an influence on student's feelings and achievement, on administration, quality and school budgets. Class size is among the determinants of students' teacher ratio and almost an administrative decision over which teachers have little or no control.

Most countries in the world spend most of their budget and resource inputs in the Education sector. They make decisions about providing resources inputs to enhance student achievement and performance. According to De Paola, Ponzo and Scoppa, (2013) class size, teachers' workload and teaching method as constructs of student-teacher ratio significantly might affect students' learning academic performance in public schools in Italy. Teachers are the principal guarantor of quality education, as such, their activities and quality greatly might influence the way students learn and their academic performance.

United State of America (USA) has 21 students in primary education classes and 23 students in lower secondary education (Schwartz, Schmitt and Lose 2012). This average number of students in one class may improve teachers teaching process while students on their side might perform better since they can participate in the lesson well. Class size is a good indicator of teachers' workload and teacher availability to students (Etomes and Lyonga, 2020). It seems that a high number of students in class scale down the contact time that a teacher has for each student an aspect that is necessary for a meaningful impartation of knowledge and skills. If students are more than teachers this leads teachers overwhelmed 
and also hold many student's failures in their studies. This is related to Kenya where class size was seen to be highly caused by students' poor performance (Wanyonyi\&Kangangi, 2019).

Large class size affects Kenya Certificate of Secondary Education (KCSE) performance by either leading to low physical contact between teachers and students hence poor understanding of concepts and poor individual attention to every student. Kenya education sector is considering class reduction to improve academic performance (Murithi, 2014). Reducing class size is a promising intervention that will increase academic achievement on average for all students.

There is a concern about the quality of education being provided in Tanzanian secondary schools. Different people at different times have passed the blame of poor academic performance to the government (URT, 2018). The secondary school education has recently arisen in the awareness among people in Tanzania and the demand to access this education has grown (Ajani \&Akinyele, 2014). The growth in demand has created the need to build more schools and classrooms in order to expand access opportunities among the children of the country. Tanzania has a total number of 4,796 Secondary Schools, among which 3,604 (75.1\%) are government owned schools and 1,192 (24.9\%) are non-government schools.

Teachers are working hard to improve students' academic performance, but if their hard work cannot be seen, the results can be counterproductive. A teacher might need to establish several teaching strategies like the use of group discussion that students can learn on their own. This may reduce the teacher workload. The teacher's workload includes teaching subjects, administrative duties, supervision of students and other activities. The maximum teaching load is thirty periods per week while the minimum is twenty-two periods per week, while others may have more than maximum particularly science subjects, however, this policy is not strictly adhered to. Some teachers may be allocated less than maximum teaching periods, whereas others may have more than the maximum. This might affect students' academic performance if teachers are not applying effective teaching strategies to encourage students to study on their own.

Secondary Education Development Plan (SEDP) has helped to form Education Sector Development Plan (ESDP) between 2004-2009 (URT, 2018). Large class size has caused many problems in terms of learning in Arumeru District and poor academic performance whereby Komba et al., (2015) mentioned factors influencing their bad performance are shortage of teachers, shortage of classrooms, un-conducive teaching and learning environments, and poor teaching and learning materials.

Shortage of teaching and learning materials in large class size might affect students' academic performance. The distribution of little resource available in Tanzania public secondary schools is a great challenge to most of Tanzanian teachers.

\section{Statement of the Problem}

There is a concern on the students' academic performance in form four national examination in public secondary schools in Tanzania. Regardless of effective supervision done by the government official through MOEST to supervise teachers teaching process for the purpose of improving form four students' performance in national examination, still there is no improvement of students' performance in their final exams. Moreover, it has been reported that teachers were found to teach a class which have large number of students compared to its capacity and hence students were not full participated during teaching and learning (Wanyonyi\&Kangangi, 2019).

Not much has been explained on the strategies used by teachers who teach large class size to enhance students' performance in their national examination. Various studies like De Paola, Ponzo and Scoppa, (2013); Blatchford \& Lai, (2012); Wanyonyi\&Kangangi, (2019) have been tried to explain the effects of large class size on students' academic performance in the national examination by relating several factors like teacher workload, teaching and learning materials and school infrastructures. However, none of the studies have been discussed the provision of teaching and learning materials by teachers in large class size to enhance students' performance in form four national examinations. This has made a researcher to investigate the provision of teaching and learning materials by teachers in large class size to enhance students' performance in form four national examination in Arumeru District

\section{Research Objectives}

This seminar paper was guided by the following research questions

- To enhance students' performance in Form Four National Examination in Arumeru District with the problem of large class size.

\section{Significance of the Study}

This study was expected to bring awareness to the Ministry of Education Science and Technology on the strategies used by the strategies used by teachers in large class size to enhance students' performance in Form Four National Examinations. Those strategies were expected to help students to effectively participate during teaching and learning process and hence improve their academic performance. The findings of the study were also to raise awareness to the students on the importance of strategies formulated by teachers in large class size to enhance their academic performance. The study also was also expected to contribute knowledge on the challenges facing teachers in implementing strategies in large class size to enhance students' performance.

\section{Theoretical Framework}

This seminar paper was guided by the Social Constructivism Theory which developed by post-revolutionary Soviet psychologist Lev Vygotsky (1978). 


\subsection{Strengths of the Social Constructivism Theory}

Social constructivism focuses on the collaborative nature of learning. Knowledge develops from how people interact with each other, their culture, and society at large. Students rely on others to help create their building blocks, and learning from others, helps them construct their own knowledge and reality.

\subsection{Weakness of the Social Constructivism Theory}

Meaningful learning is therefore a product of three interacting components, the student, the teacher and the learning environment. If well planned and executed in lessons the three components promote meaningful and permanent learning among the students. However, constructivist learning theory lacks structure.

\subsection{Application of Social Constructivism Theory}

The theory provides conceptual tools to be used by teachers when teaching the class with large number of students, since teacher must emphasize the collaborative learning methods which make all students in the class to participate during teaching and learning process. Collaborative learning methods require learners to develop teamwork skills and to see individual learning as essentially related to the success of group learning. The optimal size for group learning is four or five people. Since the average section size is ten to fifteen people, collaborative learning methods often require GSIs to break students into smaller groups, although discussion sections are essentially collaborative learning environments.

\section{Review of Empirical Studies}

This section involves review of empirical studies. The studies are reviewed in order of the themes derived from research question for the purpose of identifying research gaps for each research question.

\subsection{Provision of Teaching and Learning Materials by Teachers in Large Class Size to Enhance Students'Performance}

Elsayed, (2017) conducted a study about instructional strategies for large classes: baseline literature and empirical study of secondary school teachers in Uganda. The adopted quantitative design whereby cross-sectional design was used. The questionnaire was used to collect data from 24 teachers, 60 students and 2 heads of schools. The study found that teachers in large classes use textbooks, reference books, pamphlets, handouts, study guides, manuals, charts, real objects, photographs and transparencies during teaching and learning. The study design cannot be used to analyse behaviour over a while since it involves the collection of data from the sample size at one time. Similarly, the study was based only on statistical data that was collected by using a questionnaire and hence the findings lack respondents' emotions and feeling about the study problem. The current study used a mixed research paradigm which involves the collection of both qualitative and quantitative data to gain more understanding of the study problem.

A qualitative study was done by Kanyamwenge, (2017) about the teachers use of instructional materials when teaching large class size in secondary school teachers in Nairobi, Kenya. Interviews, observations, and document analysis were the instruments used for the study. Twenty government aided schools in Kampala and Wakiso districts; 35 teachers (4 males and 31 females) and 20 school administrators participated in the study. The study revealed that teachers used textbooks and videos during teaching literature classes. Teaching large classes from peer tutoring, novel practices including issues on the environment for change are suggested. The implication for these findings is the need for teacher professional development through reflective practice. The sample size of the study was little bit small to represent the whole target population in the district. This reflects inadequate data collected from the respondents and cannot be generalized to the target population. The study design did not provide statistical data hence it could not have reliable information from the respondents because respondents can answer questions based on the current understanding. The current study used aconvergent design that combines the virtues of both qualitative and quantitative data whereby quantitative data allows making generalizations and qualitative data provides information about the context.

Maliva (2017) did a study about the class size and instructional materials in Tanzania. The study employed mixed methods and descriptive design. Purposive sampling was used to get schools and teachers because it was only schools that had English as a major subject in the municipality that was selected. The findings reveal that most public secondary schools experienced overcrowded classrooms and a shortage of teaching and learning materials and facilities. The study design does not match with the sample size since the design allows the collection of data from more than two categories of respondents but the study sampled only teachers. Similarly, the study did not clear the instructional materials used by teachers when teaching large class sizes. Therefore, the current study sampled students, teachers and heads of schools to get data from different categories to gain more understanding of the study problem.

Sarah (2020) did a study about the importance of instructional materials in teaching English as a second language in Chemba District, Tanzania. The study used a mixed research approach while questionnaires, interviews and documentary reviews were used to collect data. 1 District education officer, 5 Ward education officers, 2 head teachers and 2 public secondary school teachers were sampled for the study from 89 schools. Most of the teachers of Chemba district faced the overcrowded issue.

\section{Methodology}

According to Magigi (2015), research design corresponds to a plan of the entire research process. It caters both quantitative and qualitative aspects (Creswell \& Creswell, 2018). The targeted population was (1589) form four students, (360) teachers, (30) heads of schools from 30 public secondary schools and one district education officer. According to Gay and Airasian (2003), a sample of ten to twenty (10-20\%) percent is acceptable for mixed research depending on the 
nature of the study. Therefore, ten percent (10\%) was considered adequate for effective representative and sufficient information that was obtained from heads of schools, teachers and students. In this study, therefore, the sample size consisted of 4 heads of school's equivalent to 13.3 per cent, 48 teachers equivalent to 13.3 per cent, 160 students equivalent to 10.0 per cent from 4 public secondary schools and 1 district education officer, making a number of 213 respondents equivalent to 11.1 per cent of all sampled respondents.

The researcher edited, coded, and organized both quantitative and qualitative data into a way that made interpretations possible before drawing conclusions. For quantitative data, the researcher used both descriptive and inferential statistics to organize the collected data. Descriptive analysis was involved organizing data in terms of frequency, percentages and means where computer software that is statistical package for social science (SPSS) version 22 was used. Inferential analysis was involved in the use of statistical techniques to test the study hypotheses whereby independent sample t-test was used at 95\% confidence level. Tables cross tabulation and charts were used to present the quantitative data. Qualitative data was verbally transcribed and analysed using narration then merging the results.

\section{Findings and Discussion}

The study sought to investigate the how provision of teaching and learning materials in large class size enhance students' academic performance.

The information to address this research question was acquired from students, teachers, heads of schools and District Education Officer. The researcher used questionnaire to get information from students and teachers while interview guide was used for heads of schools and District Education Officer. Table 1 present the responses of students on the provision of teaching and learning materials in large class size to enhance students' academic performance.

\begin{tabular}{|c|c|c|c|c|c|c|c|c|c|c|c|}
\hline \multirow{2}{*}{$\begin{array}{c}\text { Teaching and Learning } \\
\text { Resources }\end{array}$} & \multicolumn{2}{|c|}{ SD } & \multicolumn{2}{|c|}{$\mathbf{D}$} & \multicolumn{3}{|c|}{ U } & \multicolumn{3}{|c|}{ A } & \multicolumn{3}{c|}{ SA } & Mean \\
\cline { 2 - 13 } & $\mathbf{f}$ & $\mathbf{\%}$ & $\mathbf{f}$ & $\mathbf{\%}$ & $\mathbf{f}$ & $\mathbf{\%}$ & $\mathbf{f}$ & $\mathbf{\%}$ & $\mathbf{f}$ & $\mathbf{\%}$ & $\mathbf{( M )}$ \\
\hline Text books & 0 & 0.0 & 5 & 3.1 & 15 & 9.4 & 52 & 32.5 & 88 & 55.0 & 4.39 \\
\hline Reference books & 6 & 3.8 & 19 & 11.9 & 3 & 1.9 & 35 & 21.9 & 97 & 60.6 & 4.24 \\
\hline Supplementary Materials & 44 & 27.5 & 36 & 22.5 & 7 & 4.4 & 47 & 29.4 & 26 & 16.3 & 2.84 \\
\hline Multimedia and digital resources & 52 & 32.5 & 39 & 24.4 & 35 & 21.9 & 34 & 21.3 & 0 & 0.0 & 2.32 \\
\hline Syllabus Subject. & 7 & 4.4 & 15 & 9.4 & 0 & 0.0 & 55 & 34.4 & 83 & 51.9 & 4.20 \\
\hline Lesson notes & 0 & 0.0 & 3 & 1.9 & 0 & 0.0 & 44 & 27.5 & 113 & 70.6 & 4.65 \\
\hline Illustrate pictures & 52 & 32.5 & 68 & 42.5 & 0 & 0.0 & 32 & 20.0 & 8 & 5.0 & 2.22 \\
\hline Audio tape & 62 & 38.8 & 68 & 42.5 & 12 & 7.5 & 10 & 6.3 & 8 & 5.0 & 1.96 \\
\hline TV/videos & 96 & 60.0 & 58 & 36.3 & 5 & 3.1 & 1 & 0.6 & 0 & 0.0 & 1.44 \\
\hline Chalk/felt pens/markers & 0 & 0.0 & 0 & 0.0 & 0 & 0.0 & 33 & 20.6 & 127 & 79.4 & 4.79 \\
\hline Total mean & & & & & & & & & & & 3.31 \\
\hline
\end{tabular}

Table 1: Provision of Teaching and Learning Materials in Large Class Size to Enhance Students' Performance Source: Field Data, (2021) Key: SD = Strongly Disagree, D = Disagree, U= Undecided, A= agree, SA= Strongly Agree

Data from Table 1show that students were agreed that they are provided teaching and learning materials to enhance their academic performance by mean score $(M)=3.31$. For example, $127(79.4 \%)$ of students strongly agreed that chalk/ felt pen/ markers are provided to the students and few 33 (20.6\%) of students were agreed to be provided with chalk/ felt pen/ markers. Majority of students indicated that lesson notes are provided by their teachers 113 (70.6\%) while $44(27.5 \%)$ of students agreed to be provided with lesson notes however some students were disagreed that they are not provided lesson notes. The findings show that 97 (60.6\%) of students strongly agreed that they provided reference books from their teachers, another 35 (21.9\%) of students agreed that they are being received reference books from their teachers. However, 19 (11.9\%) of students disagreed that they are not provided with reference books by their teachers and $6(3.8 \%)$ of students strongly disagreed on the item they are not provided with reference books. The findings imply that students in large class size are provided with limited and necessary teaching and learning materials by teachers that is students in groups in large class size can use during teaching and learning process.

This might be due to the high enrolment of students, which is caused by fee free secondary education policy. As a result, shortage of resources that are required to be distributed in the class by the teachers during teaching and learning process fall short. The distribution of little resource available in Tanzania public secondary schools have been a great challenge to most of Tanzanian teachers due to the fact that students are many compared to a number of books available and other teaching facilities.

Heads of schools were interviewed concerning the available teaching and learning materials which are used during teaching and learning process to enhance students' academic performance. Majority of heads of schools agreed about availability of teaching and learning materials in their schools but they are in adequate to be used by all students. Results from the heads of schools indicated that in most of public secondary schools they have shortage of teaching and learning materials. The responses from teachers were summarized in Table 2. 


\begin{tabular}{|c|c|c|c|c|c|c|c|c|c|c|c|}
\hline $\begin{array}{c}\text { Teaching and Learning } \\
\text { Materials }\end{array}$ & \multicolumn{2}{|c|}{ SD } & \multicolumn{2}{|c|}{ D } & \multicolumn{2}{|c|}{ U } & \multicolumn{3}{|c|}{ A } & \multicolumn{3}{|c|}{ SA } & Mean \\
\cline { 2 - 13 } & $\mathbf{f}$ & $\mathbf{\%}$ & $\mathbf{f}$ & $\mathbf{\%}$ & $\mathbf{f}$ & $\mathbf{\%}$ & $\mathbf{f}$ & $\mathbf{\%}$ & $\mathbf{f}$ & $\mathbf{\%}$ & $\mathbf{( M )}$ \\
\hline Text books & 0 & 0.0 & 0 & 0.0 & 0 & 0.0 & 18 & 37.5 & 30 & 62.5 & 4.63 \\
\hline Reference books & 0 & 0.0 & 6 & 12.5 & 2 & 4.2 & 25 & 52.1 & 15 & 31.3 & 4.02 \\
\hline Supplementary Materials & 0 & 0.0 & 1 & 2.1 & 0 & 0.0 & 20 & 41.7 & 27 & 56.3 & 4.52 \\
\hline $\begin{array}{c}\text { Multimedia and digital } \\
\text { resources }\end{array}$ & 12 & 25.0 & 13 & 27.1 & 6 & 12.5 & 11 & 22.9 & 6 & 12.5 & 2.71 \\
\hline Syllabus Subject. & 0 & 0.0 & 4 & 8.3 & 3 & 6.3 & 23 & 47.9 & 18 & 37.5 & 4.15 \\
\hline Lesson notes & 0 & 0.0 & 0 & 0.0 & 0 & 0.0 & 10 & 20.8 & 38 & 79.2 & 4.79 \\
\hline $\begin{array}{c}\text { Illustrate pictures, Graphics \& } \\
\text { interactive data }\end{array}$ & 2 & 4.2 & 4 & 8.3 & 2 & 4.2 & 22 & 45.8 & 18 & 37.5 & 4.04 \\
\hline Audio tape & 21 & 43.8 & 14 & 29.2 & 6 & 12.5 & 5 & 10.4 & 2 & 4.2 & 2.02 \\
\hline TV/videos & 26 & 54.2 & 11 & 22.9 & 4 & 8.3 & 3 & 6.3 & 4 & 8.3 & 1.92 \\
\hline Chalk/felt pens/markers & 0 & 0.0 & 6 & 12.5 & 4 & 8.3 & 19 & 39.6 & 19 & 39.6 & 4.05 \\
\hline Total mean score & & & & & & & & & & & 3.69 \\
\hline
\end{tabular}

Table 2: Teachers Responses on the Provision of Teaching and Learning Materials in

Large Class Size to Enhance Students' Performance

Source: Field Data, (2021) Key: SD = Strongly Disagree, D = Disagree, U= Undecided, A= agree, SA= Strongly Agree

The findings in table 2 show the responses of teachers on the provision of teaching and learning materials in large class size to enhance students' performance by total mean score $(M)=3.69$. The results imply that teachers were provided teaching and learning materials in large class size and enhance students' academic performance. For example, 38 (79.2\%) of teachers strongly agreed to the item six that they are provide lesson notes to students, also $10(20.8 \%)$ of teachers agreed to provide lesson notes. Furthermore, $30(62.5 \%)$ of teachers strongly agreed and $18(37.5 \%)$ of teachers agreed to the item one that they provide textbooks in large class size to enhance students' performance. Additionally, 27 (56.3\%) of teachers strongly agreed and $20(41.7 \%)$ of teachers agreed to the item three that they provide supplementary materials to large class size to enhance students' academic performance. The findings indicate that teachers provide materials in large class size to facilitate learning process and enhance students' academic performance. During an interview that was conducted with District Education Officer concerning the distribution of teaching and learning materials. This means that the District Education Officer is distributing teaching and learning resources to the public secondary schools' despite of large number of students. Also, the findings show that District Education Officer encourage teachers to interact teaching and learning materials with students the purpose of mastering what they have been taught by the teachers. Maliva (2017)maintained that teaching and learning materials are considered important in teaching and learning in all levels of education because textbooks and other resource materials are basic tools. Absence or inadequacy makes teachers handle subjects in an abstract manner, portraying it as dry and non-exciting. For example, textbooks, charts, maps, audio-visual and electronic instructional materials such as radio, tape recorder, television and video tape recorder contribute much in making learning more interesting. This means that the importance of instructional materials is contribution more in the performance of students.

The researcher observed that teachers were distributing reference books before starting the lesson. Provision of reference books to students improve students' ability to answering various questions that was asked by the teachers. The researcher also observed that teachers were provided supplementary materials like models, maps, past papers, fliers, improvised teaching materials to students when teaching large class size. Provision of supplementary materials to students provide room for students to understand well lesson and perform good in their final examination.

Secondary schools, whose teachers use more teaching and learning materials, perform better than secondary schools, whose teachers do not use teaching and learning materials. Sarah (2020) highlighted that private schools performed better than public schools with sufficient and quality teaching and learning resources. From this importance, schools need to improve the quality and adequate teaching and learning materials (Tija, 2017).

\section{Conclusion}

The study reveals that teaching materials play a significant role for large class rooms. Textbooks, reference materials, posters are the most popular teaching materials. This study also revealed that teachers prefer to attend several seminars. As per them, seminars help them to improve their materials and style of teaching. Seminars help them to make the class session very interesting to the students which result students to master the subject. Moreover, all the teachers agreed to use teaching and learning materials are important in contributing to students' academic performance; they show a need to have these materials in their classrooms.

\section{Recommendation}

The study recommended that, the government should increase number of textbooks and reference books at every school to enhance good academic performance of students. The government should invest much in improving teaching and learning environment. This can be done by particularly building classrooms and providing necessary teaching and learning resources proportional to the number of students enrolled at a particular school. For instance, appropriate number of human resources (teachers respectively), and so having appropriate teacher/students' ratio at schools. Heads of schools 
should emphasize teachers to improvise teaching and learning materials to students during the lesson. Teachers should provide teaching and learning materials to enhance academic performance of students.

\section{References}

i. Ajani, I. R., \&Akinyele, O. B. (2014). Effects of Student-Teacher Ratio on Academic Achievement of Selected Secondary School Students in Port Harcourt Metropolis, Nigeria. Journal of Education and Practice, 8.

ii. Ajayi, O. V., Audu, C. T., \& Ajay, E. E. (2017). Influence of class size on students' classroom discipline, engagement and communication: A case study of senior secondary schools in Ekiti state, Nigeria. Sky Journal of Educational Research, 5(5), 8.

iii. Aoumeur, H. (2017). The Impact of Class Size on Teaching and Learning English as a Foreign Language: The Case of the Department of English at AbdelhamidIbnBadis University. Arabu World English Journal, 8(2), 13.

iv. Blatchford, P., \& Lai, K. C. (2012). Class Size: Arguments and Evidence. In B. McGraw, E. Baker, \& P. P. Peterson (Eds.), InternationalEncyclopaedia of Education (3rd ed.). Oxford, UK: Elsevier.

v. Creswell, J. W. \& Creswell, J. S, (2018). Educational research: planning, conducting, and evaluating quantitative and qualitative research (4th ed). Boston: Pearson.

vi. De Paola, M., Ponzo, P. M. \&Scoppa, V. (2013). Class Size effects on Students Achievement in Italy: Heterogeneity across Abilities and Fields. University Della Calabria Working Paper No. 19.

vii. Elsayed, K. M. (2017). Large Size Class Teaching Strategies: Book Review. International Journal of Business and Statistical Analysis, 1(1), 6.

viii. Etomes, S. E., \&Lyonga, F. I. (2020). Student-Teacher Ratio and Students' Academic Performance in Public Universities: The Case of the University of Buea, Cameroon. European Journal of Education Studies, 7(6), 29.

ix. Gay, L. R., \&Airasian (2003). Educational Research: Competencies for Analysis and Applications (7th ed.). Upper Saddle River, NJ: Merrill/Prentice Hall.

x. Koc, N., \&Çelik, B. (2015). The Impact of Number of Students per Teacher on Student Achievement. Procedia Social and Behavioral Sciences, 177, 65-70. https://doi.org/10.1016/j.sbspro.2015.02.335

xi. Komba, O. Kizza, U. Mtelu, J. K \&Mkoma, S. T. (2015). Shortage of Teachers in Improving Academic Performance. Procedia - Social and Behavioral Sciences, 177, 65-70.

xii. Magigi, W. (2015). Dissertation Development and Report Writing. Moshi: Safi Publishers and Trading Co. Ltd.

xiii. Maliva, W. (2017). Teaching Strategies Employed by ACSE English Teachers in Implementing CBLT in Tanzania. International Journal of Languages' Education, 1(1), 1010-1019. https://doi.org/10.18298/ijlet.2404

xiv. Murithi, P.M. (2014), Socio Economics Determinants of Girls performance in Agriculture in mixed Day Secondary Schools in Kirinyaga Central sub county, Kirinyaga County, Kenya.

xv. Nakabugo, M. G., Opolot-Ukurut, C., Ssebbunga, C. M., Ngobi, D. H., Maani, J. S., Gumisiriza, E. L., Mbaga, R., Alupo, C., Byamugisha, A., Tukesiga, J., Bisikwa, R., Ndawula, R., \&Bbosa, D. (2008). Instructional Strategies for Large Classes: Baseline Literature and Empirical Study of Primary School Teachers in Uganda. International Journal for Cross-Disciplinary Subjects in Education (IJCDSE), 4(3), 10.

xvi. Okumu, I. M., Nakajjo, A. and Isoke, D. (2008). Socio-Economic Determinants of Primary School Dropout: The Logistic Model Analysis.

xvii. Philip, E. A. (2016). The impact of over-crowded classrooms to teachers and students; Interaction in the process of teaching and learning in selected primary schools in Arusha City Council, Tanzania. Journal of Humanities and Education Development (JHED), 1(4), 9.

xviii. Sarah, C. (2020). Teacher's Coping Strategies in The Management of Overcrowded Classrooms in Public Secondary Schools in Chemba District, Tanzania [Thesis]. University of Dodoma.

xix. Schwartz, R., Schmitt, M., \& Lose, M. (2012). Effects of Teacher-Student Ratio in Response to Intervention Approaches. The Elementary School Journal, 112, 547-567. https://doi.org/10.1086/664490

xx. Secondary Education Development Plan, \& Secondary Education Development Plan (SEDP). (2004). Ministry of education and culture education sector development programme (No. 3; p. 75). University of Dar es salaam.

xxi. Tebabal, J., \&Kahssay, E. (2011). The role of teacher's initiation in online pedagogy" Education Training Vol. 54 No. 6, 2012 pp. 456-471

xxii. Tija, M. (2017). Assessment of Academic Performance in Secondary Schools in Tanzania: A Case of Secondary Schools in Dodoma Municipality [Thesis]. The University of Dodoma.

xxiii. United Republic of Tanzania. (2018). Education Sector Performance report 2017/2018; Tanzania Mainland [Government Report]. Education.

xxiv. Vygotsky, Lev (1978). Mind in Society. London: Harvard University Press.

xxv. Wanyonyi, S., \&Kangangi, E. (2019). The Factors Influencing Students' Academic Performance in Kenya Certificate of Secondary Education in Kirinyaga Central Sub-County, Kirinyaga County, Kenya. International Journal of Innovation Education and Research, 7(2), 1-11. https://doi.org/10.31686/ijier.Vol7.Iss4.1143 